relationships, adults with learning disabilities should, like anybody else, have the right to say yes as well as to say no, and these decisions cannot be made for one adult by another. ${ }^{19}$ There is, however, no legislation in the United Kingdom that specifically allows for the protection of adults who may be vulnerable or at risk in this way. The Sexual Offences Act (1956) does not address the issues of risk and vulnerability, and guardianship under the Mental Health Act (1983) relates to supervision of care and treatment rather than protection. The emphasis on legislation to remove the victim rather than the perpetrator of abuse perpetuates the tendency to blame the victim rather than to provide him or her with care and protection.

The situation is further complicated by the seldom used but significant legal concept of a "defective" (usually equivalent to someone with severe learning disabilities).$^{20} \mathrm{It}$ is an offence for a man to have unlawful sexual intercourse (that is, outside marriage) with a female defective. Being incompetent, a defective is incapable of giving consent. If this was interpreted broadly it would mean that any sexual activity by many people with learning disabilities would be illegal. Although this may seem ridiculous, the law is meant to protect people who may be vulnerable to exploitation. ${ }^{3}$ Recently a man was sentenced to two years in prison after pleading guilty to sexual intercourse with a defective. ${ }^{21}$ This is a lighter sentence than that for rape, which varies from five years to life imprisonment. ${ }^{22}$ The ordeal of court for the rape victim is considerable and is one of the reasons why prosecution is rarely pursued. In child sexual abuse, removing the victim from where the abuse has occurred or removing the perpetrator is often regarded as important and requires social workers and sometimes the police. Where adults are concerned this is often not possible, which seriously impedes clinical management. Perpetrators may need to be kept away by incarceration, court injunction, or conditions of bail; the support of the legal system is needed to achieve this. No statutory framework exists within which social services can act, as it does where children are concerned, unless staff are allegedly involved and disciplinary action can proceed.

Management of sexual abuse should consist of a multilevel approach allowing for support for the victim, the dynamics of the family, and some work with the perpetrators. The victim often has the problem that the perpetrator is also a loved one, and the relationship includes love as well as abuse-management must be sensitive to these conflicting feelings. As in cases of child sexual abuse, adults should always be offered individual counselling or psychotherapy and family therapy should be available. Research is needed to identify the extent of the problem and to evaluate how cases are managed and the adequacy of legal protection. Services for learning disabilities need to address questions of funding, training of staff, and intęrdisciplinary coordination.

BRENDAN MCCORMACK

Consultant Psychiatrist

Harperbury Hospital and

Haringey Community Team for

People with Learning Difficulties,

St Ann's General Hospital, London N15 3TH

1 Cooke LB. Abuse and mentally handicapped adults. $B M \mathcal{1}$ 1989;299:392.

2 Dunne TP, Power A. Sexual abuse and mental handicap. Preliminary findings of a community based study. Mental Handicap Research 1990;3:111-25.

3 Gunn M. Sex abuse and adults with mental handicap: can the law help? In: Brown H, Craft A, eds. Thinking the unthinkable. London: Family Planning Association Education Unit, 1989:51-72.

4 Chamberlain A, Rauh J, Passer A, McGrath M, Burket R. Issues in fertility control for mentally retarded female adolescents: 1 . Sexual activity, sexual abuse, and contraception. Pediatrics 1984;73:445-50.

5 Baker AW, Duncan SP. Child sex abuse: a study of prevalence in Great Britain. Child Abuse Negl 1985:9:457-67.

6 Cooke LB. Abuse of mentally handicapped adults. BM7 1990;300:193

7 Glaser D, Bentovim A. Abuse and risk to handicapped and chronically ill children. Child Abuse Negl 1979;3:565-75.

8 Sinason V. Caring for those who can never live alone. Guardian 1989 Nov 11:8 (cols 1-8).

9 Sinason V. Uncovering and responding to sexual abuse in psychotherapeutic settings. In: Brown $\mathrm{H}$, Craft A, eds. Thinking the unthinkable. London: Family Planning Association Education Unit, 1989.39-49.

10 Finklehor D. Child sexual abuse: new theory and research. New York: Free Press, 1984

1 Vizard E, Tranter M. Recognition and assessment of child sexual abuse. In: Bentovim A, Elton A, Hildebrand J, Tranter $M$, Vizard $\mathrm{E}$, eds. Child sexual abuse within the family: assessment and treatment. Bristol: John Wright, 1988:59-83.

12 Vizard E. Child sex abuse and mental handicap: a child psychiatrist's perspective. In: Brown $\mathrm{H}$, Craft A, eds. Thinking the unthinkable. London: Family Planning Association Education Unit, 1989:18-27.

3 Byrne ND, McCarthy IC. Moving statutes: re-questing ambivalence through ambiguous discourse. Irish fournal of Psychology 1988;9:173-82.

14 Gardner F. Psychotherapy with adult survivors of child sexual abuse. British Joumal of Psychotherapy 1990;6:285-94.

15 Barahal R, Waterman J, Martin H. The social and cognitive development of abused children. J Consult Clin Psychol 1981;53:335-43.

6 Sinason V. Richard III, hephaestus and echo: sexuality and mentalmultiple handicap. Fournal of Child Psychotherapy 1988;14:93-105.

17 Oliver J. Successive generations of child maltreatment. Br $\mathcal{P}$ Psychiatry 1988;153:543-53.

18 Hewitt S. Sexual abuse of young persons with a mental handicap. Med Law 1989;8:403-24

19 Bicknell J. Consent and people with mental handicap. BMF 1989;299:1176-7.

20 Sexual Offences Act 1956, as amended by the Mental Health (Amendment) Act 1982. London: HMSO, 1982

Dyer C. Civil claim that breaks new ground. Guardian 1990 Sep 13:3 (cols 1-2).

22 Watts J. Rape, a high price to pay for speaking out. Observer 1990 Sept 16:47(cols 1-8).

\title{
The consequences of child sexual abuse
}

\section{Psychosocial disorders are common in adults abused as children}

The recorded frequency with which children are exposed to sexual advances from adults varies according to the definition of abuse, the age range studied, and the methods of ascertainment. Contact abuse-which ranges from inappropriate fondling to intercourse-is experienced by over $20 \%$ of girls and some $10 \%$ of boys before they reach 14 years. ${ }^{12}$ Most of the perpetrators are men known to the child, often in some position of authority such as teachers or activities leaders or trusted friends of the family. Contrary to popular opinion, relatively few abusers come from the child's immediate family.

Sexual contact between adults and children is usually an abuse of power and an exploitation of the vulnerable, which is deeply repugnant in our culture; nevertheless, some voices still question the nature of the long term impact of child sexual abuse on mental and physical health. A few authorities have questioned whether non-violent sexual contact with children does any immediate or continuing harm. A recent book, Children's Sexual Encounters with Adults, claims that boys' sexual encounters with older men "are, for the most part, fairly innocuous" and that "adult child [sexual] relationships in general are possibly neither coercive nor in themselves damaging to the children involved." ${ }^{3}$ This attempt to minimise the impact of sexual abuse is coupled with an apologia for paedophiles, who are described as "men who approach boys . . . looking for what amounts to a love relationship" and who "employ gradual and gentle persuasion."

At the other end of the spectrum of child sexual abuse the raised awareness among the general public and health professionals may, on occasion, lead to a state of mind that 
finds sexual victims everywhere. False accusations of child sexual abuse do occur, particularly in the context of custody disputes, when one partner may consciously or unconsciously suggest, encourage, and shape the child's accusations. Until recently a great injustice was done to victims of child sexual abuse by ignoring their plight as children and attributing their accounts as adults to oedipal and incestuous fantasies. When panic about child sexual abuse produces witch hunts for child molesters there is a risk of replacing one form of injustice with another.

Clearly the immediate impact of child sexual abuse has the potential to produce behavioural and psychological problems. ${ }^{4}$ Studies of adults who report having been abused as children suggest increased rates of psychiatric disorders and sexual problems in adult life. Such evidence has been drawn from studies of groups of patients, self identified victims, and students and from community surveys employing random sampling techniques. The most powerful support for a correlation between child sexual abuse and later psychiatric disorders has come from studies of representative community samples using standardised psychiatric measures..$^{5-9}$

People giving a history of child sexual abuse have increased rates of depressive disorders, anxiety disorders, and alcohol and drug abuse. Community studies suggest that the risks of victims of child sexual abuse developing mental disorders in adult life are increased two to 12 times. ${ }^{10}$ The rigorous studies are consistent in showing a strong, specific, and coherent association between child sexual abuse and long term psychiatric problems. The questions that remain are not whether there is such an association but about the mechanisms that mediate between that abuse and later disorder.

How, then, could West claim in a recent review that retrospective surveys of population samples of adult women have found no detectable long term effects in most of those who recall childhood sexual contacts with older people?" This is strictly correct if possibly misleading: there may be a substantial increase in psychopathology even if more than half those sampled are unaffected. Drunk drivers don't always have accidents and only occasionally kill and maim, but who would counsel greater acceptance of such behaviour on this basis?

The level of child sexual abuse in our societies is a scandal, and the educational, health, and justice services should be making efforts to reduce it. Most men who use children for sexual purposes are not violent or sadistic; though sometimes insensitive and brutal, they are often inadequate people with limited capacities for emotional and sexual expression. Though their stunted development may evoke sympathy, their acts cannot be regarded as other than damaging and potentially dangerous to children. Doctors need to be alert to the possibilities of child sexual abuse, both in children and as a contributing factor to a wide range of psychiatric and social problems in adult life.

Professor of Psychological Medicine,

University of Otago Medical School,

PO Box 913,

Dunedin,

New Zealand

PAUL E MULLEN

1 Finkelhor D, Hotaling G, Lewis IA, Smith C. Sexual abuse in a national survey of adult men and women: prevalence characteristics and risk factors. Child Abuse Negl 1990;14:19-28.

Siegel JM, Sorenson SB, Golding JM, Burman MA, Stein JA. The prevalence of childhood sexual assault. Am $\mathcal{F}$ Epidemiol 1987; 126:1141-53.

3 Li CK, West DJ, Woodhouse TP. Children's sexual encounters with adults. London: Duckworth 1990

4 Finkelhor D. A sourcebook on child sexual abuse. Beverley Hills, California: Sage Publications, 1986

5 Bagley C, Ramsay R. Sexual abuse in childhood: psychological outcomes and implications for social work practice. Fournal of Social Work and Human Sexuality 1986;4:33-47.

6 Mullen PE, Romans-Clarkson SE, Walton VA, Herbison GP. Impact of sexual and physical abuse on women's mental health. Lancet 1988;i:841-5.

7 Stein JA, Golding JM, Siegel JM, Burnam MA, Sorenson SB. Long-term psychological sequelae of child sexual abuse: the Los Angeles epidemiologic catchment area studv. In: Wyatt GW, Powell GJ, eds. Lasting effects of child sexual abuse. Beverley Hills, California: Sage Publications GJ, eds. Lasin

8 Peters SD. Child sexual abuse and later psychological problems. In: Wyatt GE, Powell GJ, eds. Lasting effects of child sexual abuse. Beverlev Hills, California: Sage Publications, 1988:107-17.

9 Winfield I, George LK, Swartz M, Blazer DG. Sexual assault and psychiatric disorders among a community sample of women. Am $f$ Psychiatry 1990;147:335-41.

10 Mullen PE. The long-term influence of sexual assault on the mental health of victims. $f$ Forensic Psychiatry 1990;1:13-34

11 West DJ. Incest in childhood and adolescents: long-term effects and therapy. $\mathrm{Br} \mathcal{F} \mathrm{Hosp}$ Med 1988;40:352-60.
International Physicians for the Prevention of Nuclear War (IPPNW) must be one of the most successful medical organisations ever. Established in 1981, it won the Nobel prize for peace in 1985, grew rapidly to include over 200000 million doctors from almost all countries of the world, and played an important part in dramatically reducing the chance of nuclear war. Now it is in crisis, the victim of its own success. The collapse of the iron curtain has reduced concern about nuclear war. The issue most concerning delegates at last month's meeting of IPPNW in Stockholm was whether the organisation has a future and if so what it is.

Various ingredients have come together to make IPPNW so successful. Most important have been the clarity, focus, and importance of its mission-to abolish the possibility of nuclear war and rid the world of nuclear weapons. This is a mission that all doctors-from east and west, north and south-can subscribe to. Nuclear war threatens everybody everywhere, holding even the possibility of destroying the species. Also crucial was the quality of IPPNW's leadership: Bernard Lown from Boston and Evgueni Chazov from Moscow worked together to provide direction and motivation at a time when the temperature of the cold war was glacial. The organisation also benefited from being élitist, however uncomfortable it felt to many doctors at the beginning. Concentrating on doctors as members made it easier to cross boundaries: cardiologists from Venezuela can talk with cardiologists from Korea in a way that social workers or nurses cannot match. Doctors also carry more clout than most other groups in most societies.

The main challenge for IPPNW now is to redefine its mission, and the danger is that what emerges will be too woolly. As well as being clear and focused the mission should capitalise on the other strengths of IPPNW. Thus it should take on a huge and immediate threat to everybody everywhere to which doctors can make a special contribution.

Stockholm hummed with ideas. One proposal was to stick with something close to the original mission. The chance of the United States and the Soviet Union mutually destroying each other may be much reduced, but there are almost as many nuclear weapons in the world as ever. The chance of massive destruction is still present, not least because nuclear weapons are spreading to countries like Iraq. But people do 